\title{
Wastewater from Biodiesel Purification: Electroflocculation Treatment and Iron Perchloride Synthesis for Printed Circuit Boards Production.
}

\author{
Samara Pereira Vieira ${ }^{1}$, Fernando Carlos Ferreira Oliveira ${ }^{2}$, \\ Fabiano Almeida Nascimento ${ }^{3}$ Luiz Antônio Pimentel Cavalcanti ${ }^{4}$ \\ ${ }^{1,2}$ (Electrical Engineering Department, Federal Institute of Bahia, Brazil) \\ ${ }^{3,4}$ (Academic Department, Federal Institute of Bahia, Brazil)
}

\begin{abstract}
Biodiesel production by alkaline catalysis on methane route generally requires a purification step, generating wastewater that presents contaminating components in its composition, preventing it to be disposed, as established in CONAMA Resolution No. 430/2011. Reuse Alternatives and practical applications aiming to minimizing the water contamination has been the target of several studies on scientific community. Electroflocculation process was used to treat wastewater from biodiesel purification stage. This treatment was carried out in an electrochemical reactor composed of rectangular iron electrodes $9 \mathrm{~cm}$ long and $3 \mathrm{~cm}$ wide. Electrodes were fixed in a $0.5 \mathrm{~L}$ beaker through a metal structure, and wires were soldered for connection of a 2.0 A DC current source, powered by a photovoltaic system. The resulting effluent composed mainly of iron chloride II was oxidized by addition of hydrogen peroxide to iron chloride III (iron perchloride). Supernatant solution was separated for coagulation tests and the residual solution had its $\mathrm{pH}$ decreased to 1.0. Subsequently, the final solution was concentrated in an oven during $6 \mathrm{~h}$ at $90^{\circ} \mathrm{C}$. Iron perchloride solution obtained from waste waters of biodiesel was used to make printed circuit boards.
\end{abstract}

Keywords: Iron Perchloride, Residual Water, Electroflocculation, Printed Circuit Boards

\section{Introduction}

Growing concern about climate change, water scarcity and declining world oil reserves has contributed to several studies by global scientific community on this theme. Biofuels are low in toxicity, biodegradable, renewable and capable of substantially reduce greenhouse gases emissions. These characteristics make biomass fuels be considered as potential substitutes for fossil fuels [1]. Biodiesel appears as an alternative to petroleum diesel, defined as a fuel composed by alkyl esters of long chain fatty acids derived from vegetable oils, animal fats, residual oils or algae [2]. The consumed biodiesel in Brazil is generally obtained by homogeneous alkaline transesterification, in which a purification step is necessary to separate the glycerin formed as a by-product. The purification process is followed by washing with acidic solution to remove unreacted oil residues from the catalyst and finally some washes with distilled water to remove remnants of residues still present in biodiesel. This post-wash water contains high amount of wastes, so it must be treated before reuse or disposal [3]. Biodiesel purifying conventional process with water, despite having significant efficiency, generates a large volume of liquid effluent. Generally three liters of water is consumed for each liter of biodiesel produced in average, which due to present impurities cannot be directly discarded, as established by CONAMA Resolution No. 430/2011[4]. Among various treatment processes for biodiesel purification wastewater, electroflocculation occupies a prominent position. The process uses electrolysis to separate impurities and clean water. Physical and chemical effluent variables reduction (BOD, COD, oils and greases, turbidity and apparent color) is guaranteed by applying this simple and efficient method of separation [5]. Electroflocculation process is economically infeasible when using conventional grid electric power to electrically supply the system. Studies carried out by [6] point out that electroflocculation process for biodiesel wastewater treatment becomes economically feasible when using a photovoltaic system to supply energetically the electrochemical reactor. In [7], it was evaluated electroflocculation has effectiveness for wastewater treatment from biodiesel production with significantly satisfactory results, it achieved reduction in turbidity (99.96\%), apparent color (81.66\%), COD (65,19\%), BOD5 $(60.37 \%)$ and oils and greases $(30.88 \%)$, for a treatment exposure time of 10 minutes and potential difference between electrodes of $7.5 \mathrm{~V}$. The same authors also suggest that treated water can be reused at biodiesel purification process. Such alternative is impracticable, since in the treated effluent there is still a high iron or aluminum residual content (depending on the used electrode). Such metals presence on biodiesel composition accelerates autoxidation reactions $[8,9]$. Simple disposal of the resulting effluent from biodiesel wastewater purification treatment via electroflocculation is not indicated, although the physical-chemical parameters are suitable according to limits established in CONAMA Resolution 430/2011 [10]. Iron or aluminum content is high and may cause contamination on aquatic environments. Therefore, reuse alternatives for the effluent 
generated in electroflocculation process should be evaluated in order to minimize the consequences of their disposal in water courses. In [5], the treatment of wastewater from biodiesel production via electroflocculation with electrodes obtained from aluminum cans reuse was analyzed, getting significant results with reduction in turbidity (97\%), COD (85\%) BOD5 (87\%), oils and greases (84\%). Authors still synthesized potassium alum from the effluent generated in the process. In printed circuit boards manufacture at electronics area, iron perchloride (ferric chloride) is commonly used as a corrosive agent. The board is usually shielded with paint and the circuit tracks will be attacked by the corrosive agent. When biodiesel is produced by homogeneous catalysis with potassium methoxide, its residual water after acid washing with hydrochloric acid $(\mathrm{HCl})$ will have as a product, after the acid-base neutralization reaction, the potassium chloride $(\mathrm{KCl})$ salt. This salt dispersed in the effluent will make iron perchloride production possible, so that can be applied in printed circuit boards manufacture. This work aimed to treat the residual wastewater of biodiesel production by methyl route via electroflocculation and, from the effluent generated at this process, synthesize the iron perchloride for use as corrosive agent at printed circuit boards.

\section{Materials And Methods}

In this section, materials and methods used during the experiments are presented.

\subsection{Materials}

The process electrolytic cell was mounted in a glass vessel, using cut and sanded iron electrodes, with dimensions of $9 \mathrm{~cm}$ long and $3 \mathrm{~cm}$ wide. An electrical DC source (brand Instrutherm, model FA 3030) was used to supply the necessary process current, connected to a photovoltaic system. Chemical compounds such as methanol, potassium hydroxide and $99 \%$ purity hydrochloric acid were purchased from VETEC, Sigma-Aldrich Brazil [6].

\subsection{Biodiesel Production}

Soybean biodiesel (B100-S) was produced by alkaline transesterification reaction in the presence of $\mathrm{KOH}$, with a molar ratio oil : methanol of $1: 6$. The processing was performed in a glass reactor (Marconi, model MA502 / 5 / C, useful volume $1 \mathrm{~L}$ ) with temperature control and mechanical agitation (blades impeller), under the following operating conditions: $50^{\circ} \mathrm{C}, 1 \mathrm{~atm}, 300 \mathrm{rpm}$ and reaction time of $1 \mathrm{~h}$. Thereafter, the glycerin was separated from reaction mixture by decantation. The mixture lighter phase, containing B100-S, catalyst and methanol excess, passed through the purification step consisting of methanol evaporation with the aid of a rotary evaporator (IKA, model RV10) with vertical condenser, followed by washes with $0.5 \mathrm{M}$ hydrochloric acid solution. $2 \mathrm{~g}$ of potassium chloride $(\mathrm{KCl})$ was added at the acid wash water to increase effluent conductivity. Subsequent washings were performed with distilled water. The total wastewater resulted from purification process was collected in suitable containers and subjected to electroflocculation treatment [11].

\subsection{EleCtroflocCulation DisPositive}

The wastewater treatment was carried out in a batch-operated electrochemical reactor (plastic beaker, useful volume $0.5 \mathrm{~L}$ ) composed of two iron electrodes, $9 \mathrm{~cm}$ long and $3 \mathrm{~cm}$ wide. The electrodes were fixed in the reactor, in which copper wires were supplied by DC source $(2.0 \mathrm{~A})$ powered by a photovoltaic system, according to the scheme shown in Figure 1. 0.2 L of the solution was added on the reactor to be treated, from the washing water obtained at biodiesel production. Subsequently, the system was operated for 10 min and the result effluent used for iron perchloride production.

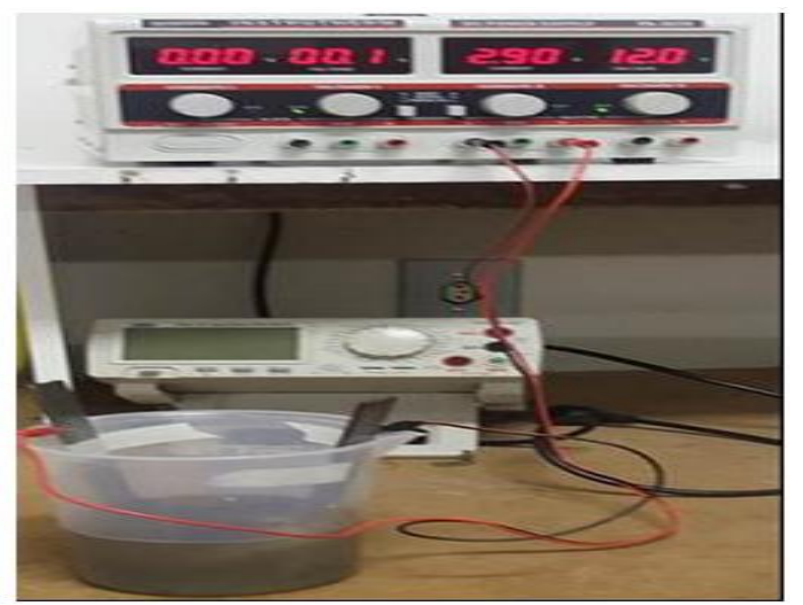

Figure 1 - Assembled electrochemical reactor for electroflocculation of wastewater from biodiesel purification process 


\subsection{Iron PERChLORIDE Production}

On the produced effluent, from electroflocculation process, was added $0.03 \mathrm{~L}$ of $35 \%$ (v / v) hydrogen peroxide. As a next step, solution $\mathrm{pH}$ was lowered to 1.0 and left inert for $5 \mathrm{~h}$. The supernatant solution was removed with the aid of a graduated pipette, while the residual solution was oven-dried at $90^{\circ} \mathrm{C}$ for $6 \mathrm{~h}$.

\subsection{Printed Circuit Board Manufacture}

A virgin phenolic printed circuit board was cut into appropriate dimensions of the circuit to be inserted. Oxidations were removed from the surface of the plate with sandpaper. Subsequently, a layer of paint was applied with the aid of a permanent pen (usually used on CDs, DVDs). The drawing of the traces on the plate was done manually, removing the ink layer, where it was desired that the iron perchloride would act as a corrosive agent. Subsequently, the plate was immersed in the iron perchloride solution under stirring for 5 min. At the last step, the ink was removed, and the plate was perforated at the spots for electronic components, where they were inserted and welded [12].

\section{Results And Discussion}

The obtained effluent from biodiesel production wastewater treatment by electroflocculation is predominantly composed of ferrous chloride $\left(\mathrm{FeCl}_{2}\right)$ as a result of electrolysis of potassium chloride and iron dispersed in the effluent. The liquid presented a greenish coloration, characteristic of ferrous chloride presence as showed in Fig.1. Generally, two classical methods are used for oxidation of $\mathrm{Fe}^{2+}$ ions in $\mathrm{Fe}^{3+}$ : the first consists in exposing ferrous chloride to atmospheric air, leaving the container open. According to [12], this method is ineffective because the reaction rates are extremely low and produce high concentrations of rust; In the second method, which was used in this work, the addition of hydrochloric acid eliminates the presence of rust, increasing process efficiency.

The hydrochloric acid eliminates the rust due to the attack of this acid (1), in addition it decreases the solution $\mathrm{pH}$. $\mathrm{HCl}$ was added until solution $\mathrm{pH}$ was 1.0. Then, the hydrogen peroxide was added, which more efficiently oxidized $\mathrm{Fe}^{2+}$ ions in $\mathrm{Fe}^{3+}(2)$, and there was a changing of color on the solution from greenish (characteristic color of $\mathrm{Fe}^{2+}$ ions) to a reddish coloration (characteristic of $\mathrm{Fe}^{3+}$ presence), in just $2 \mathrm{~min}$, the $0.5 \mathrm{~L}$ content presented reddish color which is indicative that the solution was converted to iron perchloride. The system was allowed to stand for $5 \mathrm{~h}$, as previously described.

It was verified precipitation of iron chloride and a supernatant solution of non-concentrated iron chloride. This was removed with the aid of a graduated pipette. The solution can then be used for coagulation tests of effluents with suspended solids and also in water treatment or industrial sewage systems [13]. The precipitated solution was taken to the oven at $90^{\circ} \mathrm{C}$ for $6 \mathrm{~h}$ to evaporate water excess aiming to concentrate iron perchloride solution.

$$
\begin{aligned}
& \mathrm{Fe}(\mathrm{OH})_{3(a q)}+\mathrm{HCl}_{(a q)} \Rightarrow \mathrm{FeCl}_{3(a q)}+3 \mathrm{H}_{2} \mathrm{O}_{(l)} \\
& 2 \mathrm{FeCl}_{2(a q)}+2 \mathrm{HCl}_{(a q)}+\mathrm{H}_{2} \mathrm{O}_{2(l)} \Rightarrow 2 \mathrm{FeCl}_{3(a q)}+2 \mathrm{H}_{2} \mathrm{O}_{(l)}
\end{aligned}
$$

Fig. 2a) shows the printed circuit board after ink application layer and circuit design, where the iron perchloride solution will act as a corrosive agent. Fig. 2b) shows the plate submerged in the solution; the component was exposed to the treatment for 5 min under stirring.

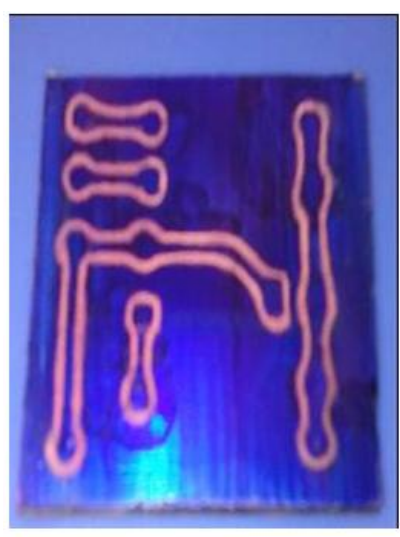

a)

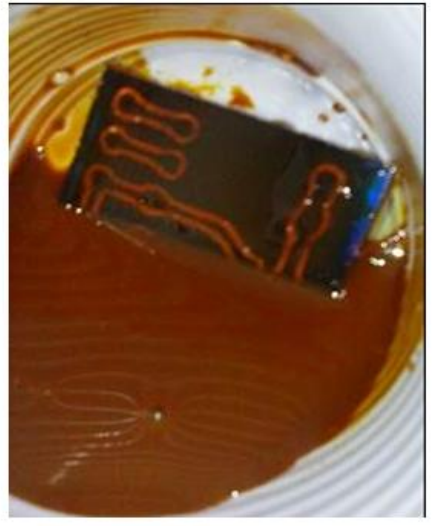

b)

Figure 2 - a) Board after ink application and b) Board submerged at iron perchlorate solution 
The produced solution of iron perchloride from wastewater of biodiesel production, treated by electroflocculation technique, proved to be efficient acting as a corrosive agent in printed circuit boards as showed in Fig. 3a).

The circuit showed in Fig. 3b) corresponds to a full-wave rectifier with central (or neutral) derivation; such circuit is used as a converter to the sine-wave periodic signal with a fixed frequency of $60 \mathrm{~Hz}$ provided by grid power supply. Usually, this source is used as electronic power supplies for electronic devices that needs continuous voltage to operate, but are connected to commonly AC grid power supply. Generally, it is located at the transformer output voltage, performing the conversion into constant voltage for DC electronic circuits. The copper traces delimited in the rest of the plate by the action of the corrosive agent are destined for electric currents conduction and they must basically be of sufficient thickness to withstand the intensity of the electric flow.

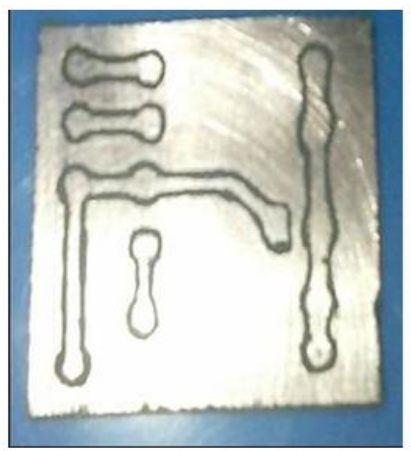

a)

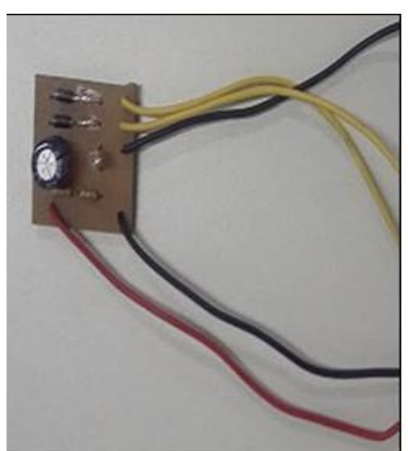

b)

Figure 3 - a) Board after corrosion and b) Final assembled circuit

\section{Conclusion}

Obtained results showed that it is possible to obtain iron perchloride from biodiesel wastewater by electroflocculation technique. It has been found that there are two possible uses, first supernatant iron chloride solution can be applied widely in water coagulation/decantation processes, which contain dispersed solids, as well as applied in industrial sewage treatment. The second application refers to the use of iron perchloride as a corrosive agent at printed circuit boards manufacture. It can be stated that for this purpose the produced iron perchloride satisfactorily met the objectives of this work.

\section{Acknowledgements}

This research was supported by the Foundation for Research Support of Bahia (FAPESB). We thank Federal Institute of Bahia by providing equipment and working space for this project.

\section{References}

[1] Dogan, T. H. \& Temur, H. (2013). Effect of fractional winterization of beef tallow biodiesel on the cold flow properties and viscosity. Fuel, 108, 793-796. doi: 10.1016/j.fuel.2013.02.028

[2] Moser, B. (2014). Impact of fatty ester composition on low temperature properties of biodiesel-petroleum diesel blends. Fuel, 115, 500-506. doi: 10.1016/j.fuel.2013.07.075

[3] Elicker, C., Flores, C. P., Santos, M. A. Z., Colepicolo, P. \& Pereira, C. M. P. (2015). Estudo da utilização da biomassa de cianobactérias como matéria-prima para a síntese de biodiesel através da reação de esterificação in situ. Revista Virtual de Química, 7 (6), 2497-2508. doi: 10.5935/1984-6835.20150149

[4] Fleck, L. (2011). Aplicação do controle estatístico de processos ao tratamento de um efluente têxtil por eletrofloculação. Final Course Thesis, Curitiba - Brazil, Universidade Tecnológica Federal do Paraná.

[5] Vieira, S. P., Nascimento, F. A., Braz, M. A., Andrade Júnior, S. J. \& CAVALCANTI, L. A. P. (2015). Reuso de latinhas de alumínio recicláveis para tratamento de águas residuais da produção de biodiesel via eletrofloculação. Revista Brasileira de Gestão Ambiental e Sustentabilidade, 2 (3), 145-151. Recuperado de http://revista.ecogestaobrasil.net/v2n3/v02n03a07.html.

[6] Nascimento, F. A., Vieira, S. A., Andrade Júnior, S. J. \& CAVALCANTI, L. A. P.(2015) . Integração de um sistema fotovoltaico isolado e de coleta seletiva de resíduos em um quiosque multifuncional. Revista Brasileira de Gestão Ambiental e Sustentabilidade, 2 (2), 43-50. Recuperado de http://revista.ecogestaobrasil.net/v2n2/v02n02a04.html.

[7] Cordeiro, R. B., Alexandre, J. I. S., Silva, J. P. F., Sales, D. C. S. \& Cavalcanti, L. A. P. (2015). Purificação e reutilização de águas residuárias da produção de biodiesel por meio da eletrofloculação. Revista Brasileira de Gestão Ambiental e Sustentabilidade, 2 (2), 51-58. Recuperado de http://revista.ecogestaobrasil.net/v2n2/v02n02a05.html.

[8] Knothe, G., Gerpen, J. V., Krani, J. \& Ramos, L. P.(2006). Manual do biodiesel. São Paulo: Edgard Blücher.

[9] Junqueira, C. N., Franco, M. M., Ruggiero, R., Borges Neto, W., Bueno, J. A. \& Santos, D. Q. (2015). Contaminantes metálicos no biodiesel de soja. Anais do $10^{\circ}$ Congresso Internacional de Bioenergia, São Paulo, 1-8.

[10] BRASIL. Resolução CONAMA nº 430, 2011. Recuperado de http://www.mma.gov.br/port/conama/legiabre.cfm?codlegi=646.

[11] Cavalcanti, L. A. P. (2013). Reologia e melhoramento das propriedades de escoamento a frio de biodiesel e suas misturas BX. doctoral thesis, Universidade Federal de Pernambuco, Recife.

[12] Silveira, R. L.; Dias, T. A.; Rodrigues, T. V.; Belo, E. M. \& Barbosa, H. C. S. (2013). Reciclagem do percloreto de ferro. Anais do XLI Congresso Brasileiro de Educação em Engenharia, COBENGE, 1-8.

[13] Silveira, R. L.; Dias, T. A.; Rodrigues, T. V.; Belo, E. M. \& Barbosa, H. C. S. (2013). Reciclagem do percloreto de ferro. Anais do XLI Congresso Brasileiro de Educação em Engenharia, COBENGE, 1-8. 